\title{
Growth performances and carcass traits in three strains of rabbits and their two-way crosses
}

\author{
J.M. Brun and J. Ouhayoun \\ INRA, BP 27, 31326 Castanet-Tolosan Cedex, France
}

(received 24 november 1988, accepted 30 may 1989)

Summary - Genetic variation of growth between 30 and 79 days and feed efficiency has been analysed on 362 rabbits from a factorial crossing design between three INRA strains : 1077 (NZ) and 9077 (C) (New Zealand White) and 1066 (CA) (Californian). Data on slaughter yield, carcass fatness and edible fraction of the hindleg have been analyzed on a sample of 152 males. Offspring of " $\mathrm{C}$ " dams grew faster and converted feed less efficiently. Slaughter yield and edible fraction of the hindleg were significantly higher in "CA" sired offspring. Direct and maternal additive genetic effects along with individual heterosis have been estimated. Whatever genetic effect was considered, an antagonism was found between growth rate and feed efficiency.

rabbit - genetics - crossbreeding - growth — carcass traits

Résumé - Performances d'engraissement et qualités bouchères de trois souches de lapln et de leurs croisements réciproques. La variation génétique de la croissance entre 30 et 79 jours et de l'efficacité alimentaire est analysée sur 362 lapins (essentiellement mâles) issus d'un plan factoriel de croisement entre les souches INRA 1077 (NZ), 9077 (C) (Néo-Zélandais blanc) et 1066 (CA) (Californien). Sur 152 mâles, sont analysés le rendement à l'abattage, l'adiposité de la carcasse et la fraction comestible du membre postérieur. Les lapereaux de mères " $C$ " ont une vitesse de croissance supérieure, mais transforment l'aliment moins efficacement. Le rendement en carcasse et la fraction comestible du membre postérieur sont significativement supérieurs chez les descendants des pères "CA". Les effets génétiques additifs directs et maternels, ainsi que l'hétérosis individuel, sont estimés. Quel que soit l'effet génétique considéré, un antagonisme entre vitesse de croissance et efficacité alimentaire est mis en évidence.

lapin - génétique - croisement - croissance - qualité bouchère 


\section{INTRODUCTION}

In the production of rabbit meat, as well as in other animal production, crossbreeding with specialized breeds or strains makes use of the complementarity between dam lines (or dam hybrids), which have a good reproductive efficiency, and sire lines. which possess a good meat production efficiency. The choice of selection objectives within these specialized lines has been studied by several authors (Smith, 1964; Moav \& Hill, 1966; Elsen \& Sellier, 1978). It should be remembered that dam lines contribute to at least one half of the growth and carcass characteristics of their offspring. This study aims to analyze these productive traits in the crosses of three strains of rabbits. Two of them are selected on prolificacy to give hybrid dams, whereas the third one is an unselected control. This study is part of a wider study on the total productivity of these strains. No study of productive performance of these strains and their crosses has yet been carried out.

\section{MATERIALS AND METHODS}

\section{Animals and experimental conditions}

Three INRA strains were studied, A 1077, A 9077 and $A$ 1066. The first two originate from the New Zealand White breed; strain A 1077 has been selected for litter size at weaning since 1976 (Matheron \& Rouvier, 1977), and strain A 9077 is its unselected control (Matheron \& Chevalet, 1977). Strain A 1066 originates from the Californian breed and has been selected for litter size at birth according to the same method as strain 1077. In the following, these strains will be named "NZ", " $\mathrm{C}$ " (for control) and "CA" respectively. The breeding animals used in this experiment came from the 14th generation of selection. These strains had an intermediate body size; however, the "C" strain at the adult stage had a body weight on average $6 \%$ higher than the other two.

This study involved 362 rabbits, the majority of which were males, issued from a $3 \times 3$ factorial crossing design, including 10 sires and 65 dams per strain. Rabbits were born between July 13 and August 31, 1987 (8 birth weeks), in litters of parity $1(25 \%), 2(73 \%)$ and $3(2 \%)$. They have been reared under the usual experimental farm conditions at the Station d'Amélioration Génétique des Animaux : weaning at 30 days, then transfer into a conventional growth room until the age of 79 days. Rabbits were housed in collective wire cages of $0.4 \mathrm{~m}^{2}$, in flat-deck and drop-to-drop drinking-trough. Each cage contained 5 or 6 rabbits of the same genotype. They were fed ad libitum a diet composed of lucerne $(35 \%)$, corn $(36 \%)$, soya oilcake $(10 \%)$, sunflower oil-cake $(5.44 \%)$, straw $(10 \%)$, complemented with methionin, minerals and vitamins $(3.56 \%)$. The diet consisted of $16.7 \%$ crude protein, $16.4 \%$ cellulose (Weende) and $2700 \mathrm{kcal}$ of digestible energy per $\mathrm{kg}$.

The individual body weight was measured at weaning and at 79 days. Food consumption was recorded by cage, taking mortality into account. When they were 79 days old, 152 male rabbits from second parity litters and from birth week number 2 to 5 were slaughtered. They were bled by cutting the jugular vein and the carotid artery, after electroanesthesia (90 V, 2 s.). Carcasses were chilled $\left(+2{ }^{\circ} \mathrm{C}\right)$ for 22 hours and then weighed. Carcass quality was estimated by weighing liver, perirenal fat and the edible part of hindleg deboned after vacuum cooking (Ouhayoun, Poujardieu \& Delmas, 1986).

Table I shows the number of rabbits recorded for growth with the corresponding number of cages and the number recorded on body composition. A large mortality during the fattening period has produced an imbalance between genotypes and simultaneously reduced the number of slaughtered rabbits.

\section{Statistical analysis}

The analysis deals with the following variables : 
Table I. Number of rabbits recorded on growth (1), slaughtered (2) and number of fattening cages (3) by genotype.

\begin{tabular}{|c|c|c|c|c|c|}
\hline & & \multicolumn{3}{|c|}{ Dam strain } & \multirow{2}{*}{ All } \\
\hline & & $c$ & $C A$ & $N Z$ & \\
\hline \multirow{3}{*}{$\begin{array}{l}\text { Sire } \\
\text { strain }\end{array}$} & $\mathrm{C}$ & $\begin{array}{l}60 \\
31 \\
16\end{array}$ & $\begin{array}{r}33 \\
6 \\
10\end{array}$ & $\begin{array}{r}37 \\
13 \\
8\end{array}$ & $\begin{array}{r}130 \\
50 \\
34\end{array}$ \\
\hline & $\mathrm{CA}$ & $\begin{array}{l}52 \\
37 \\
11\end{array}$ & $\begin{array}{r}39 \\
8 \\
11\end{array}$ & $\begin{array}{l}42 \\
23 \\
11\end{array}$ & $\begin{array}{r}133 \\
68 \\
33\end{array}$ \\
\hline & $\mathrm{NZ}$ & $\begin{array}{r}30 \\
8 \\
8\end{array}$ & $\begin{array}{l}35 \\
19 \\
10\end{array}$ & $\begin{array}{r}34 \\
7 \\
10\end{array}$ & $\begin{array}{l}99 \\
34 \\
28\end{array}$ \\
\hline \multicolumn{2}{|l|}{ All } & $\begin{array}{r}142 \\
76 \\
35\end{array}$ & $\begin{array}{r}107 \\
33 \\
31\end{array}$ & $\begin{array}{r}113 \\
43 \\
29\end{array}$ & $\begin{array}{r}362(1) \\
152(2) \\
95(3)\end{array}$ \\
\hline
\end{tabular}

\section{Growth and food consumption variables}

$$
\begin{aligned}
& \text { LW30 : live weight at } 30 \text { days } \\
& \text { LW79 : live weight at } 79 \text { days } \\
& \text { ADG : average daily gain between } 30 \text { and } 79 \\
& \text { days } \\
& \text { CI } \quad \begin{array}{l}
\text { : ratio of food consumption to weight } \\
\text { gain between } 30 \text { and } 79 \text { days }
\end{array}
\end{aligned}
$$

\section{Body composition variables}

$$
\begin{array}{ll}
\text { CW } & \text { : carcass weight } \\
\text { THW } & \text { : total hindleg weight } \\
\text { EHW } & \text { : edible weight of hindleg } \\
\text { FW } & \text { : perirenal fat weight } \\
\text { LWW } & \text { : liver weight } \\
\text { CW\% } & \text { : carcass yield (CW/LW79) } \\
\text { EHW\% : edible percentage of hindleg } \\
\text { (EHW/THW) }
\end{array}
$$

Five series of rabbits of similar size were defined, according to birth period and number of rabbits. They correspond to the birth week numbers $1,2,3$, (4 and 5), (6 to 8), respectively. Slaughtered rabbits came from serial numbers 2, 3 and 4.

Analyses of variance were performed according to the following two models :

Model 1 : with series, offspring genotype and series $x$ offspring genotype interaction as fixed effects.

Model 2 : with series, dam strain, sire strain and all 2-way interactions as fixed effects. This model therefore splits the offspring genotype effect of model 1 into three components : dam strain, sire strain and dam strain $x$ sire strain interaction effects. Maternal and paternal effects of the three strains have been compared according to Newman \& Keuls (Dagnelie, 1970).

With regard to the $\mathrm{Cl}$ variable, analyses dealt with cages and not rabbits.

Sex effect on growth traits was not included in the models. The absence of sexual dimorphism on these traits (Cantier et al., 1969) has been previously confirmed. 


\section{Genetical analysis}

Dickerson's model (1969) was used to estimate the genetic parameters of traits in this crossbreeding experiment : direct and (maternal + grand maternal) additive genetic effects $\left(g_{M}\right.$ and $\mathrm{g}^{\mathrm{M}}+\mathrm{M}$, respectively) and individual heterosis $\left(h_{M}\right)$. These parameters are linear combinations of genotypic means, the coefficients of which are given by Brun \& Rouvier (1984) in the case of a factorial crossing design between three strains. Only the traits showing a significant effect of offspring genotype have been considered in this analysis.

\section{RESULTS AND DISCUSSION}

Effects of sire, dam and offspring genotypes

Table II gives the statistical significance of the effects on growth, consumption and body composition.

All growth traits were affected by offspring genotype. Dam strain effect and

Table II. Variance analysis for growth, consumption and body composition traits.

\begin{tabular}{|c|c|c|c|c|c|c|c|c|c|c|}
\hline \multirow[b]{2}{*}{ Traits } & \multirow[b]{2}{*}{$\begin{array}{l}\text { Series } \\
\text { (S) }\end{array}$} & \multirow{2}{*}{$\begin{array}{l}\text { Model } 1 \\
\text { Offspring } \\
\text { genotype } \\
\text { (OG) }\end{array}$} & \multirow[b]{2}{*}{$\begin{array}{c}\text { Interaction } \\
S \times O G\end{array}$} & \multirow[b]{2}{*}{$\begin{array}{l}\text { Sire } \\
\text { strain } \\
\text { (SS) }\end{array}$} & \multicolumn{4}{|c|}{ Model 2} & \multirow[b]{2}{*}{$\begin{array}{l}s_{r} \\
(1)\end{array}$} & \multirow[b]{2}{*}{$\begin{array}{l}R^{2} \\
\text { (2) }\end{array}$} \\
\hline & & & & & $\begin{array}{c}\text { Dam } \\
\text { strain } \\
\text { (DS) }\end{array}$ & $\begin{array}{c}\text { Int } \\
\text { SxSS }\end{array}$ & $\begin{array}{c}\text { eraction } \\
\text { SxDS }\end{array}$ & SS $S \times D S$ & & \\
\hline LW30 & * & ** & ** & NS & $* *$ & NS & ** & ** & 106 & 0.19 \\
\hline LW79 & NS & $* *$ & * & NS & $* *$ & NS & NS & * & 272 & 0.09 \\
\hline ADG & NS & * & $* *$ & NS & $*$ & NS & NS & NS & 4.5 & 0.09 \\
\hline $\mathrm{Cl}$ & NS & " & NS & NS & NS & NS & NS & • & 0.24 & 0.12 \\
\hline $\mathrm{cW}$ & NS & $* *$ & ** & NS & ** & ** & NS & ** & 150 & 0.23 \\
\hline THW & NS & $* *$ & * & NS & $* *$ & $\star \star *$ & NS & ** & 19.7 & 0.24 \\
\hline EHW & NS & $\star *$ & $* *$ & NS & $* *$ & $* *$ & NS & $\star *$ & 17.9 & 0,24 \\
\hline FW & NS & * & ** & NS & • & * & NS & * & 66.8 & 0.17 \\
\hline LiW & NS & NS & NS & NS & $* *$ & * & NS & * & 19.4 & 0.10 \\
\hline CW\% & ** & ** & NS & ** & NS & * & NS & NS & 1.7 & 0.21 \\
\hline EHW\% & NS & ** & $* *$ & ** & NS & "* & ** & $\star *$ & 1.1 & 0.22 \\
\hline FW\% & NS & NS & * & NS & NS & NS & NS & NS & 0.44 & 0.10 \\
\hline LiW\% & NS & NS & NS & NS & NS & NS & NS & NS & 1.0 & 0 \\
\hline
\end{tabular}

NS : not significant; * $: P<0.05 ;{ }^{* *}: P<0.01$

(1) $S_{r}$ : residual standard deviation; (2) : $R^{2}=$ coefficient of determination

$S_{r}$ and $H^{2}$ are averages over models 1 and 2 
sire $x$ dam interaction accounted for offspring effect. Interaction between series and offspring genotype affected all traits, except Cl. For LW79, ADG and $\mathrm{Cl}$, two sources of interaction were not significant : series $x$ sire genotype and series $x$ dam genotype. Rabbits born from " $C$ " dams were heavier at 30 and 79 days than offspring of the other dam strains; their growth rate was the highest. Low differences in feed efficiency between offspring genotypes arose from sire strain $x$ dam strain interaction. However " $\mathrm{C}$ " strain decreased feed efficiency of its offspring, but not significantly (Table III).
Apart from liver weight, all body component weights showed the same pattern of variation as LW79. Genotypic means are given in Table IV. The significance of the effects was different when body components were expressed in percent : slaughter yield and edible percentage of hindleg were then affected by sire genotype and no longer by dam genotype. The latter trait remained dependent on sire $x$ dam interaction. Unlike perirenal fat weight, carcass fatness was not affected by offspring genotype. The biological significance of this result should be regarded cautiously because perirenal fat location is tardy in the

Table III. Growth and consumption : effects of sire, dam and offspring genotypes estimated in variance analyses.

\begin{tabular}{|c|c|c|c|c|}
\hline $\begin{array}{l}\text { Dam } \\
\text { strain } \\
\text { Sire } \\
\text { strain }\end{array}$ & $C$ & $C A$ & $N Z$ & \\
\hline C & $\begin{array}{c}616 \\
2288 \\
34.1 \\
3.10\end{array}$ & $\begin{array}{c}544 \\
2171 \\
33.2 \\
3.22\end{array}$ & $\begin{array}{c}577 \\
2176 \\
32.7 \\
3.07\end{array}$ & $\begin{array}{c}588 \\
2218 \\
33.3 \\
3.12\end{array}$ \\
\hline$C A$ & $\begin{array}{c}611 \\
2287 \\
34.2 \\
3.18\end{array}$ & $\begin{array}{c}567 \\
2100 \\
31.3 \\
2.93\end{array}$ & $\begin{array}{c}635 \\
2284 \\
33.6 \\
3.09\end{array}$ & $\begin{array}{c}601 \\
2228 \\
33.2 \\
3.08\end{array}$ \\
\hline$N Z$ & $\begin{array}{c}683 \\
2372 \\
34.5 \\
3.20\end{array}$ & $\begin{array}{c}601 \\
2186 \\
32.3 \\
3.14\end{array}$ & $\begin{array}{r}534 \\
2107 \\
32.1 \\
2.88\end{array}$ & $\begin{array}{c}607 \\
2230 \\
33.1 \\
3.06\end{array}$ \\
\hline & $\begin{array}{c}629 \\
2309 \\
34.3 \\
3.13\end{array}$ & $\begin{array}{r}570 \quad b \\
2146 \quad b \\
32.2 \quad b \\
3.10\end{array}$ & $\begin{array}{rc}585 & b \\
2194 & b \\
32.8 & b \\
3.02 & \end{array}$ & $\begin{array}{ll}\text { LW30 } & (\mathrm{g}) \\
\text { LW79 } & (\mathrm{g}) \\
\text { ADG } & (\mathrm{g} / \mathrm{d}) \\
\mathrm{Cl} & (\mathrm{g} / \mathrm{g})\end{array}$ \\
\hline
\end{tabular}

Marginal effects with different letters are significantly different $(P<0.05)$. 
Table IV. Body composition : effects of sire, dam and offspring genotypes estimated in variance analyses.

\begin{tabular}{|c|c|c|c|c|}
\hline $\begin{array}{c}\text { Dam } \\
\text { strain }\end{array}$ & $C$ & $C A$ & $N Z$ & \\
\hline & 1379 & 1385 & 1208 & 1312 \\
\hline & 189 & 196 & 162 & 180 \\
\hline \multirow[t]{5}{*}{ C } & 161 & 168 & 137 & 153 \\
\hline & 209 & 168 & 190 & 194 \\
\hline & 103 & 93 & 88 & 97 \\
\hline & 1390 & 1241 & 1373 & 1372 \\
\hline & 190 & 175 & 185 & 188 \\
\hline \multirow[t]{5}{*}{$\mathrm{CA}$} & 163 & 149 & 160 & 161 \\
\hline & 190 & 175 & 192 & 188 \\
\hline & 103 & 83 & 98 & 101 \\
\hline & 1456 & 1257 & 1341 & 1343 \\
\hline & 202 & 172 & 181 & 184 \\
\hline \multirow[t]{8}{*}{$N Z$} & 172 & 147 & 154 & 157 \\
\hline & 278 & 189 & 161 & 214 \\
\hline & 105 & 91 & 97 & 93 \\
\hline & 1401 a & $1299 \mathrm{~b}$ & $1286 \mathrm{~b}$ & $\mathrm{CW} \quad(\mathrm{g})$ \\
\hline & $192 a$ & $179 b$ & $174 \mathrm{~b}$ & THW (g) \\
\hline & $164 a$ & $154 \mathrm{~b}$ & $148 \mathrm{~b}$ & $\mathrm{EHW}$ (g) \\
\hline & $213 a$ & $180 \mathrm{~b}$ & $178 \mathrm{~b}$ & FW (dg) \\
\hline & $103 a$ & $95 \mathrm{ab}$ & $91 \mathrm{~b}$ & LiW (g) \\
\hline
\end{tabular}

rabbit and consequently variable. "CA" sired offspring showed the highest slaughter yield (60 vs 59,0 and 59,3\%); " $\mathrm{C}$ " sired one exhibited the lowest edible percentage of hindleg (84.9 vs 85.5 and $85.6 \%$ ) (Table V).

The lower feed efficiency (higher $\mathrm{Cl}$ ) of " $\mathrm{C}$ " dams' offspring which had a faster rate of growth, does not agree with the usual results (i.e. Ollivier \& Henry, 1978, in pigs; Ouhayoun, 1978, in rabbits). This could be explained by their greater fatness and higher maintenance requirements due to their heavier body weight. Another contra- diction is the lesser degree of maturity (52 vs $58 \%$ in the two others) despite the greater fatness (non significant) of " $\mathrm{C}$ " dams' offspring.

\section{Crossbreeding parameters (Table VI)}

Growth traits are less dependent on direct genetic effects than on maternal ones. A significant direct genetic effect appeared only in LW30, with a superiority of "CA" strain. This effect is probably due to the 
Table V. Body composition : effects of sire, dam and offspring genotypes estimated in variance analyses.

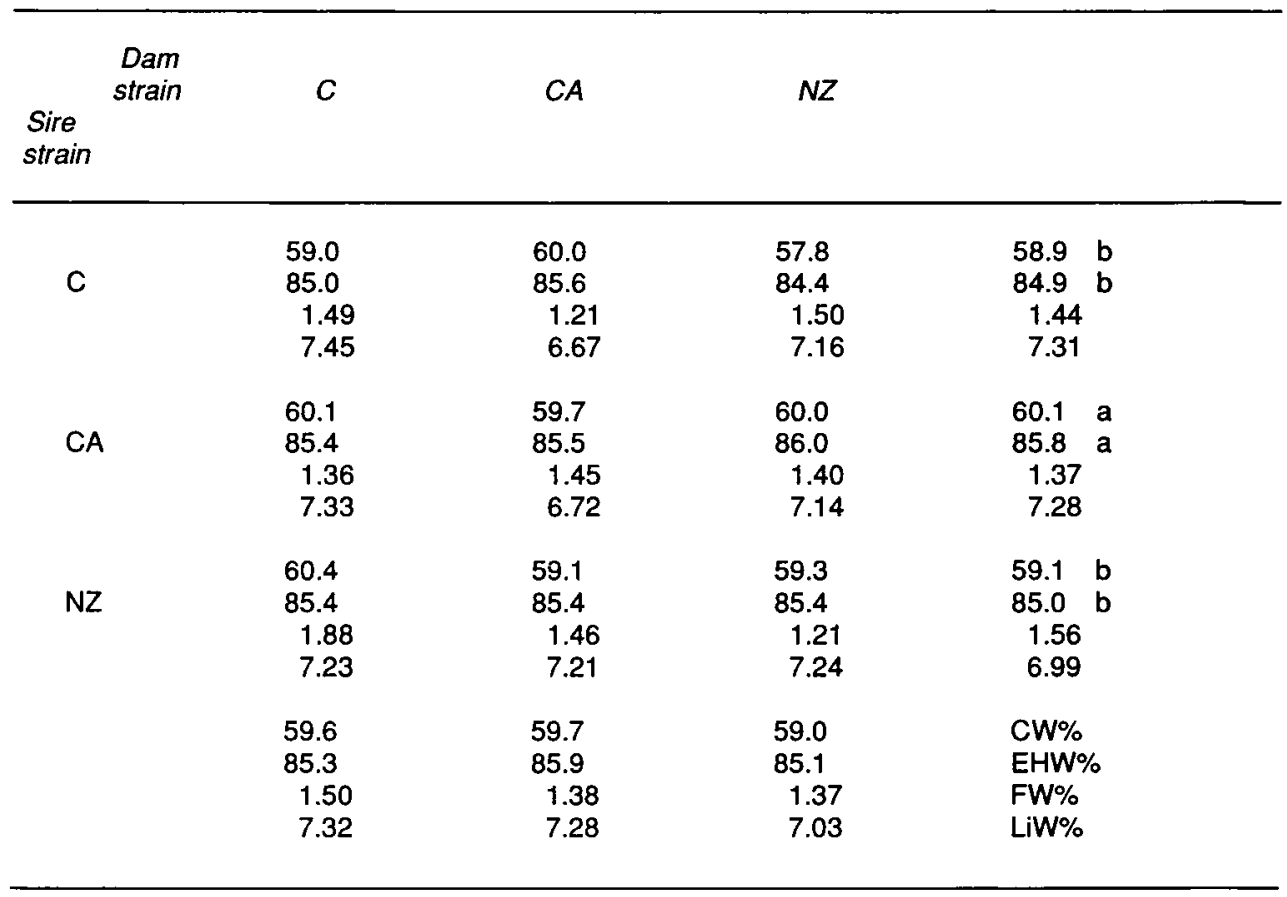

negative direct effect of this strain on litter size at weaning (Brun \& Rouvier, 1988). The expected superiority of the direct effects of " $\mathrm{C}$ " strain (the heaviest at the adult stage) on LW79 and ADG was not significant. Whatever growth trait was considered, the three strains ranked as follows for maternal effects : "C" > "NZ" > "CA", the relative superiority of " $\mathrm{C}$ " strain decreasing between 30 and $79 \mathrm{~d}$. The ranking of strains for maternal effects on growth was exactly opposite to that for the number of ova shed (Bolet et al., 1988). The latter arose on one hand from breed differences in ovulation rate between "CA" and "NZ" (Hulot \& Matheron, 1981) and on the other from the selection for litter size in these strains (Matheron \& Rouvier, 1977). In this experiment, no significant additive effect was observed on feed efficiency $(\mathrm{Cl})$.

A direct heterosis effect was noticed in all growth traits, averaging $5 \%$ and particularly in crosses involving "NZ" strain. The direct heterosis between the strains "CA" and "NZ" in LW30 was higher here than was the case with earlier estimates (Brun \& Rouvier, 1984, 1988). Feed efficiency appeared to be reduced by crossbreeding. The antagonism between growth rate and feed efficiency mentioned before appeared again.

Slaughter yield and the edible part of the hindleg were moderately but significantly influenced by additive effects but not by heterosis effects. On slaughter yield, an 
Table VI. Genetic parameters (SE) of growth and carcass traits according to Dickerson's model.

\begin{tabular}{|c|c|c|c|c|c|c|c|}
\hline & & $\angle W 30$ & $\angle W 79$ & $A D G$ & $\mathrm{Cl}$ & $C W \%$ & $E H W \%$ \\
\hline $\mathrm{g}^{\prime}$ & $\begin{array}{l}\mathrm{C} \\
\mathrm{CA} \\
\mathrm{NZ}\end{array}$ & $\begin{array}{l}-14(17) \\
+28^{*}(15) \\
-14(18)\end{array}$ & $\begin{array}{l}+19(43) \\
+\quad 6(40) \\
-25(47)\end{array}$ & $\begin{array}{l}+0.7(0.7) \\
-0.4(0.7) \\
-0.2(0.8)\end{array}$ & $\begin{array}{l}+0.10(0.08) \\
-0.07(0.13) \\
-0.03(0.08)\end{array}$ & $\begin{array}{l}-1.2^{*}(0.5) \\
+0.7(0.6) \\
+0.5(0.6)\end{array}$ & $\begin{array}{l}-0.6^{*}(0.3) \\
+0.3(0.4) \\
+0.2(0.4)\end{array}$ \\
\hline $\mathbf{g}^{M+M^{\prime}}$ & $\begin{array}{l}\mathrm{C} \\
\mathrm{CA} \\
\mathrm{NZ}\end{array}$ & $\begin{array}{l}+58^{*}(12) \\
-34^{*}(11) \\
-24^{*}(11)\end{array}$ & $\begin{array}{l}+104^{*}(29) \\
-\quad 71^{*}(29) \\
-33(28)\end{array}$ & $\begin{array}{l}+0.9^{*}(0.5) \\
-0.8^{*}(0.5) \\
-0.2(0.5)\end{array}$ & $\begin{array}{r}0.03(0.05) \\
0.03(0.05) \\
-0.06(0.05)\end{array}$ & $\begin{array}{l}+0.9^{*}(0.4) \\
-0.3(0.3) \\
-0.6^{*}(0.3)\end{array}$ & $\begin{array}{l}+0.3(0.2) \\
-0.1(0.2) \\
-0.1(0.2)\end{array}$ \\
\hline$h_{M}$ & $\begin{array}{l}\mathrm{CA} \times \mathrm{NZ} \\
\mathrm{CA} \times \mathrm{C} \\
\mathrm{NZ} \times \mathrm{C} \\
\text { overall mean }\end{array}$ & $\begin{array}{c}12.3^{\star} \\
-2.4 \\
9.6^{\star} \\
6.5\end{array}$ & $\begin{array}{l}6.3^{*} \\
1.6 \\
3.5^{*} \\
3.8\end{array}$ & $\begin{array}{l}3.9^{*} \\
3.1 \\
1.5 \\
2.8\end{array}$ & $\begin{array}{l}7.2^{*} \\
6.1^{*} \\
4.8^{*} \\
6.0\end{array}$ & $\begin{array}{r}0.1 \\
1.2 \\
-0.1 \\
0.4\end{array}$ & $\begin{array}{r}0.3 \\
0.3 \\
-0.4 \\
0.1\end{array}$ \\
\hline
\end{tabular}

$g^{\prime} \quad=$ direct additive genetic effect.

$\mathrm{g}^{\mathrm{M}+\mathrm{M}^{*}}=$ sum of maternal and grand-maternal additive genetic effect.

$h_{M} \quad=$ individual heterosis, in percent of the parental mean.

$=$ different from zero $(P<0.05)$.

antagonism between direct and maternal effects was pointed out. In particular, " $\mathrm{C}$ " strain exhibited unfavourable direct effects, but favourable maternal ones.

\section{CONCLUSION}

Under the conditions of this experiment, significant differences between strain in growth performances and carcass traits have been pointed out. The unselected control strain (C) exerts favourable maternal effects on growth. With respect to carcass quality, strain CA seems to transmit the best direct effects on both the slaughter yield and meat yield of the carcass. An experiment currently underway will allow us to prove these results.

\section{ACKNOWLEDGMENTS}

We are grateful to Danielle Delmas and F. Lebas for their contribution to this experiment, as well as to the staff of both laboratories, particularly J. Falières, A. Falourd, Véronique Tartie and Gisèle Fort.

\section{REFERENCES}

Bolet G., Brun J.M. \& Hulot F. (1988) Relationships between ovulation rate and embryonic survival in various strains of rabbits. Proc. 4th World Rabbit Congress, Budapest, October 1014, 1988

Brun J.M. \& Rouvier R. (1984) Effets génétiques sur les caractères des portées issues de trois souches de lapins utilisées en croisement. Génét. Sél. Evol. 16, 367-384 
Brun J.M. \& Rouvier R. (1988) Paramètres génétiques des caractères de la portée et du poids de la mère dans le croisement de deux souches de lapin sélectionnées. Génét. Sél. Evol. 20, 367-378

Cantier J., Vezinhet A., Rouvier R. \& Dauzier L. (1969) Allométrie de croissance chez le lapin (Oryctolagus cuniculus). I. Principaux organes et tissus. Ann. Biol. Anim. Bioch. Biophys. 9, 5-39

Dagnelie P. (1970) Théorie et Méthodes Statistiques. Vol. 2, 281-287. Ed. Duculot, Gembloux

Dickerson G.E. (1969) Experimental approaches in utilizing breed resources. Anim. Breed. Abstr. 37, 191-202

Elsen J.M. \& Sellier P. (1978) Etude conjointe de l'intérêt de la sélection sur la prolificité et de l'utilisation d'une lignée mâle spécialisée chez le Porc. Ann. Génét. Sél. Anim. 10, 403-441

Hulot F. \& Matheron G. (1981) Effet du génotype, de l'âge et de la saison sur les composantes de la reproduction chez la lapine. Ann. Génét. Sël. Anim. 13, 131-150

Matheron G. \& Chevalet C. (1977) Conduite d'une population témoin de lapins. Evolution à court terme du coefficient de consanguinité individuel selon le schéma d'accouplement. Ann. Génét. Sél. Anim. 9, 3-15

Matheron G. \& Poujardieu B. (1984) Expérience de sélection de la taille de portée chez le lapin.
In : Proc. 3rd World Rabbit Congress, Rome, April 4-8, 1984

Matheron G. \& Rouvier R. (1977) Optimisation du progrès génétique sur la prolificité chez le lapin. Ann. Génét. Sél. Anim. 9, 393-405

Moav R. \& Hill W.G. (1966) Specialized sire and dam lines IV. Selection within lines. Anim. Prod. 8, 375-387

Ollivier L. \& Henry Y. (1978) Variations génétiques de l'efficacité alimentaire chez le porc en croissance : interaction avec les conditions nutritionnelles. Ann. Génét. Sél. Anim. 10, 191208

Ouhayoun J. (1978) Etude comparative de races de lapins différant par le poids adulte. Incidence du format paternel sur les composantes de la croissance des lapereaux issus de croisement terminal. Thèse, Université des Sciences et Techniques du Languedoc. Montpellier, $72 \mathrm{p}$. + annexes

Ouhayoun J., Poujardieu B. \& Delmas D. (1986) Etude de la croissance et de la composition corporelle de lapins au delà de l'âge de 11 semaines. II.-Composition corporelle. $4^{\theta}$ Journées de la Recherche Cunicole en France, Paris, 1011 décembre, communication 24, 1-13, INRAITAVI

Smith C. (1964) The use of specialized sire and dam lines in selection for meat production. $J$. Anim. Sci. 23, 337-344 